\title{
THE EFFECT OF LISTENING EDM GENRE TO STUDENTS' PRONUNCIATION
}

\author{
Sigit Yuliadi ${ }^{1}$, Sultan Arief Padana ${ }^{2}$, Rasi Yugafiati ${ }^{3}$ \\ ${ }^{1}$ IKIP Siliwangi Bandung, Terusan Jendral Sudirman street, Cimahi, West Java, Indonesia \\ ${ }^{2}$ IKIP Siliwangi Bandung, Terusan Jendral Sudirman street, Cimahi, West Java, Indonesia \\ ${ }^{3}$ IKIP Siliwangi Bandung, Terusan Jendral Sudirman street, Cimahi, West Java, Indonesia \\ 1'kimsulthan@gmail.com,2²igitbandung94@gmail.com , ${ }^{3}$ tanya.rasiyugafiati@gmail.com
}

\begin{abstract}
Music dynamics is now infiltrated on the development of EDM (Electronic Dance Music) genre. Characteristics of those songs combine the beat, effects, and repetition of words. Those reasons make the EDM genre lovers dance. The genre is commonly found in bars, pubs, night clubs, performance and event venues (venues and appearances). This music genre is also found in radio and cable tv. Interestingly, the lyrics of the genre mostly use English. Although in this country, the lyrics sometimes are found in Bahasa. The lyrics in the EDM genre tend to be repetitive. Thus, the possibility of memorizing the lyrics in English may be higher. Memorize the lyrics in direct use when listening to the EDM genre, giving music lovers chance to produce acceptable pronunciation. The purpose of this study is to examine the mastery of English pronunciation through the lyrics of the EDM genre. The study involves three participants. This study uses descriptive qualitative method. The result of this research is that all participants feel helpful in improving English pronunciation ability by using EDM genre.
\end{abstract}

Keywords: EDM (Electronic Dance Music), Pronunciation Ability, English lyric

\section{INTRODUCTION}

English is one of the foreign languages commonly used by people in Indonesia. English has the special role in Indonesia. It is believe that English can be used as a tool of communication. The evidence is government of Indonesia put English as one of the lesson in high school for a long time. Thus, English as foreign language has been examined in Indonesia. Sometimes the student will get anxiety in facing English examination, especially in listening section, because they have lack of vocabulary. However, the way to decrease the level of anxiety is increasing vocabulary. On the other hand the problem is they have low motivation in listening toefl preparation. Commonly, they may enjoy listen to the music than listen to toefl preparation for improving the listening skill. Generally, the music has lyrics. Lyrics can help them in to produce English better. The researcher would like to give the easy way in understanding English by using lyrics of song. The students able to study something closely how message revealed from its lyrics, and found out the synonym of several words (Aimah, 2011).

Pronunciation or speech is a person's speech ability about how the notices the sound system. Furthermore, it affects one's speech. Thus, it will straight affect the meaning or connotation if in the English context. In English, different sounds diverge with meaning, let alone different script, and will greatly influence spoken communication. On the other pointer, language skills are not only inscribed skills but also verbal, and ironically, most people communicate verbally. Inappropriate speech will be the average that a person is unable to learn the language as entire. It is an indicator that there must be a way to do so can be minimized. 
Hopefully, education system can be changed to be better. This incongruity is caused by one of which is the difference of concept in a language learned in the mother tongue.

Different sound systems, psychological states that touch learning, the situation around the place of study, and the different facilities will affect the concept of understanding between students. Many theories that mentions the psychological or psychological disorder of a person greatly affect the result of a lesson. If a person feels happy and comfortable, usually someone will learn faster because of more motivation and reassurance big.

\section{EDM music}

Music is one of the entertainment that from the past until now is still growing rapidly and still much favored by all circles of society. Music itself has many genres ranging from the slow rhythm until the fast rhythm. One of the genre of music that is trending is EDM. Music EDM is one of the development of western music that entered into Indonesia as part of popular music. EDM is the driver of global digital music growth and global artist sales (D.LANGDON \& C.LAI, 2013). In music psychology education, everyone needs music because music has an effect on humans that can be associated with everything such as physical, emotional, one's behavior, education, and imagination (Rukmana, 2015). The research about the influence of music has been done, and the positive impact found. EDM as the music that can be found easily in the sophisticated era, has become the research's object that is interesting to be analyzed.

\section{Pronounciation}

pronunciation is one of the basic requirements of learners' competence and it is also one of the most important features of language instruction (Gilakjani, 2016). According to Garcia (2007), English pronunciation is one of the most difficult skills to acquire and learners should spend lots of time to improve their pronunciation (Gilakjani, 2016). Hence, many research done to get the best way to enhance the pronunciation ability. In this research, the author use EDM music as the medium of instruction, because music believed can create comfortable learning environment that give positive effect to learning processes.

\section{METHOD}

This research is mainly descriptive qualitative. Descriptive research draws the collected data without any goals to get the general conclusion (Sugiyono, 2012). This study is conducted in IKIP Siliwangi Bandung. There are three participants in the research. This study employs some data collection techniques, using one questionnaire as instrument, classroom observation, interview, and document analysis as triangulation. The data analysis in this study is conducted over the course. All the data gained from the data collections are analyzed gradually. The data from questionnaires are transcribed and subsequently categorized, then interpreted to answer the research questions. The triangulations from interview, classroom observation, and document analysis are also interpreted descriptively. 


\section{RESULTS AND DISCUSSION}

\section{Results}

The table below shows about the results of the research.

Table 1. The Result of the Research

\begin{tabular}{|c|c|c|c|c|c|c|}
\hline No & Name & $\begin{array}{c}\text { Felling about EDM } \\
\text { MUSIC }\end{array}$ & $\begin{array}{c}\text { UNDERSTANSDING } \\
\text { SPEAKING } \\
\text { ENGLISH FROM } \\
\text { EDM MUSIC } \\
\end{array}$ & $\begin{array}{c}\text { EDM CAN } \\
\text { INPROVE } \\
\text { Speaking } \\
\text { Skill } \\
\end{array}$ & $\begin{array}{c}\text { DIFFIUCULT TO } \\
\text { Speaking Skill }\end{array}$ & $\begin{array}{c}\text { The } \\
\text { Effectiveness } \\
\text { LISTEN } \\
\text { EDM MUSIC }\end{array}$ \\
\hline S1 & fenia & $\begin{array}{l}\text { really enjoying every } \\
\text { tone and rhythm }\end{array}$ & $\begin{array}{l}\text { searched for the } \\
\text { meaning of his lyrics } \\
\text { and did the repetition } \\
\text { of the music. }\end{array}$ & $\begin{array}{l}\text { can affect our } \\
\text { speaking } \\
\text { skills because } \\
\text { it can speak } \\
\text { English } \\
\text { before it }\end{array}$ & $\begin{array}{l}\text { sometimes the singer } \\
\text { recites it vaguely }\end{array}$ & $\begin{array}{l}\text { very effective } \\
\text { for the music } \\
\text { repertory }\end{array}$ \\
\hline S2 & $\begin{array}{l}\text { Rena } \\
\text { alsyfa }\end{array}$ & $\begin{array}{c}\text { very excited when } \\
\text { listening to EDM } \\
\text { music }\end{array}$ & $\begin{array}{l}\text { when the singer put it } \\
\text { quickly and can not } \\
\text { understand the meaning } \\
\text { of the lyrics }\end{array}$ & $\begin{array}{l}\text { very helpful } \\
\text { with the } \\
\text { music get us } \\
\text { to hear the } \\
\text { English } \\
\text { language } \\
\text { song quickly }\end{array}$ & $\begin{array}{l}\text { little can be less } \\
\text { understood when the } \\
\text { singer melafakannya } \\
\text { quickly }\end{array}$ & $\begin{array}{c}\text { can be a } \\
\text { medium to } \\
\text { speak english } \\
\text { quickly }\end{array}$ \\
\hline S3 & $\begin{array}{c}\text { Andi } \\
\text { wiguna }\end{array}$ & $\begin{array}{l}\text { feel enjoy and happy } \\
\text { when listening to } \\
\text { EDM songs }\end{array}$ & $\begin{array}{l}\text { when singers sing } \\
\text { quickly sometimes it's } \\
\text { hard to understand }\end{array}$ & $\begin{array}{l}\text { can add new } \\
\text { vocabulary in } \\
\text { pronunciatio } \\
\text { n }\end{array}$ & Nothing & $\begin{array}{l}\text { because EDM } \\
\text { music is simple } \\
\text { to hear and easy } \\
\text { to pronounce } \\
\text { english } \\
\text { vocabulary }\end{array}$ \\
\hline
\end{tabular}

\section{Discussion}

From the table 1 above, there are 3 participants in the research. the first question explains about the feeling of listening to music EDM.S1 answered really enjoy the music EDM. S2 answered very happy when listening to EDM music and after listening to EDM music. S3 answered enjoy while listening and enjoying every rhythm of EDM music.

Based on table 1 above there are 3 participants in the research giving opinion about understanding to listen EDM music. S1 replied when he heard the song EDM music he looked for the meaning of the lyrics and did repetition of his music to understand what the singer sang. While S2 replied When the singer said quickly sometimes unclear and can not understand the meaning of the lyrics. S3 said when singers sing quickly sometimes difficult to understand

From the table 1 above, there are 3 participants in the reaserch giving answer from question about EDM music can speaking skill . S1 answered can affect the ability to speak in English because it can speak English before. S2 said very helpful with EDM music to make listeners hear English songs quickly capture what is said and its meaning. S3 can add new vocabulary in English pronunciation

Based on the table 1 above, there are 3 participants response on the difficulty can speaking skill. SI answered when listening to music EDM Sometimes the singer read it vaguely and unclear. while the S2 answered while listening to music EDM Little that can be less understood when the singer said quickly. while S3 No san can be well understood. 
Moreover, based on the table 1 above, there are 7 participants response on the effectiveness of the listening EDM music. S1 responded very effectively to the music repertory. besides S2 answer can be media english quickly. as well as S3 answers that said Because EDM music is easy to hear and easy to pronounce english vocabulary.

\section{CONCLUSION}

The Conclusion should the results of this research journal is the effect of music EDM that is able to improve one's English skills and add new vocabulary in English. often the meaning of the music EDM songs sometimes contain unfavorable meanings or less good intentions for listeners of EDM music while those who love to speak english is able to interpret quickly. and also they often recite the EDM song to train the ability to speak English the listener. therefore dati to 3 researchers concluded that music EDM greatly affect the performance and ability of how to get a new vocabulary in English.

\section{ACKNOWLEDGMENTS}

The source of any financial support received for the work being published is independent.

\section{REFERENCES}

Aimah, M. I. (2011). KEEFEKTIFAN LAGU SEBAGAI MEDIA BELAJAR DALAM PENGAJARAN. jurnal unimus, 363-370.

Brown, H. (2004). Language Assesment Principles and Classroom Practices. USA: Pearson Education, Inc.

Clark, H. H., \& Clark, E. (1997). Psychology and Language. New York: Harcort Javanovich.

D.LANGDON, J., \& C.LAI, J. (2013). Electronic Dance Music (EDM): The Digital Panagea. LOS ANGELES: MASSIVE ADVISORS,LLC.

Gilakjani, A. P. (2016). English Pronunciation Instruction: A Literature Review. International Journal of Reaserach in English Education, 1-6.

Sugiyono. (2012). Memahami Penelitian Kualitatif. Bandung: CV. Alfabet. 